\title{
Growth, puberty, and bone health in children and adolescents with inflammatory bowel disease
}

Hye-Young Jin ${ }^{1}$, Jae-Sang Lim², Yena Lee², Yunha Choi ${ }^{2}$, Seak-Hee Oh², Kyung-Mo Kim², Han-Wook Yoo ${ }^{2}$ and Jin-Ho Choi ${ }^{2^{*}}$ (i)

\begin{abstract}
Background: Endocrine complications such as impaired growth, delayed puberty, and low bone mineral density (BMD) can be associated with inflammatory bowel disease (IBD) in children and adolescents. This study was performed to investigate the frequency, characteristics, and outcomes of endocrine complications of IBD in children and adolescents.

Methods: This study included 127 patients with IBD diagnosed before 18 years of age [117 with Crohn disease (CD) and 10 with ulcerative colitis (UC)]. Growth profiles, pubertal status, 25-hydroxyvitamin $\mathrm{D}_{3}\left[25(\mathrm{OH}) \mathrm{D}_{3}\right]$ levels, and BMD were reviewed retrospectively.

Results: Short stature was observed in 14 of 127 (11.0\%) with a mean height-SDS of $-2.31 \pm 0.72$. During a 2-year follow-up period, height-SDS did not significantly improve, while weight-SDS significantly improved. Among 109 patients who were older than 13 (girls) or 14 (boys) years of age during the study period, 11 patients (10.1\%) showed delayed puberty, which was associated with low weight-SDS. Vitamin D deficiency was documented in $81.7 \%(94 / 115)$ with the average $25(\mathrm{OH}) \mathrm{D}_{3}$ level of $14.5 \pm 7.0 \mathrm{ng} / \mathrm{mL}$. Lumbar BMD Z-score was below -2 SDS in 25 of 119 patients (21.0\%). Height-SDS, weight-SDS, and body mass index (BMI)-SDS were lower in patients with osteoporosis than those without osteoporosis. When pediatric CD activity index scores were high ( $\geq 30)$, weightSDS, BMI-SDS, insulin-like growth factor 1 (IGF-1)-SDS, and testosterone levels were significantly decreased.

Conclusions: Vitamin D deficiency and osteoporosis are common in pediatric IBD patients. As disease severity deteriorates, weight-SDS, IGF-1-SDS, and testosterone levels were decreased. Optimal pubertal development is necessary for bone health.
\end{abstract}

Keywords: Growth, Puberty, Bone mineral density, Inflammatory bowel disease, Crohn disease, Ulcerative colitis

\footnotetext{
* Correspondence: jhc@amc.seoul.kr

${ }^{2}$ Department of Pediatrics, Asan Medical Center, University of Ulsan College of Medicine, 88, Olympic-Ro 43-Gil, Songpa-Gu, 05505 Seoul, Republic of Korea

Full list of author information is available at the end of the article
}

(C) The Author(s). 2021 Open Access This article is licensed under a Creative Commons Attribution 4.0 International License, which permits use, sharing, adaptation, distribution and reproduction in any medium or format, as long as you give appropriate credit to the original author(s) and the source, provide a link to the Creative Commons licence, and indicate if changes were made. The images or other third party material in this article are included in the article's Creative Commons licence, unless indicated otherwise in a credit line to the material. If material is not included in the article's Creative Commons licence and your intended use is not permitted by statutory regulation or exceeds the permitted use, you will need to obtain permission directly from the copyright holder. To view a copy of this licence, visit http://creativecommons.org/licenses/by/4.0/. The Creative Commons Public Domain Dedication waiver (http://creativecommons.org/publicdomain/zero/1.0/) applies to the data made available in this article, unless otherwise stated in a credit line to the data. 


\section{Background}

Inflammatory bowel disease (IBD) is a chronic relapsingremitting inflammatory condition divided into two phenotypes: Crohn disease (CD) and ulcerative colitis (UC) [1]. The global incidence and prevalence of IBD has been increasing worldwide [2]. The incidence and prevalence of IBD in Asia remains low compared with the incidence and prevalence seen in Western countries; however, this gap has been narrowing in recent years [3]. The mean prevalence of IBD in the total population of Western countries is estimated at $1 / 1000$, while the prevalence in Korea has been reported to be 29.6/100, 000 in CD and 66.0/100,000 in UC [4-6]. Among patients with IBD, approximately $25 \%$ of patients manifest symptoms before the age of 18 years [7]. The highest reported annual pediatric incidence of IBD is 23 cases per 100,000 person-years in Europe and 11.4 cases per 100, 000 person-years in Asia [8]. In Korea, recently published local data shows that incidence of pediatric IBD increased from 0.86 to 100,000 in 2011 to 3.33 per 100, 000 in 2016 [9].

Previous studies have investigated the frequency and clinical characteristics of endocrine complications in children and adolescents with IBD, such as impaired growth, delayed puberty, and low bone mineral density (BMD) [10-16]. Growth profiles can help clinicians diagnose IBD in children and adolescents because growth retardation is commonly noted at diagnosis, and decreased height velocity has been reported to be the first clinical sign of IBD in $46 \%$ of patients [7, 17]. Approximately $10-33 \%$ of pediatric IBD patients manifested short stature (height $<3$ rd percentile) at diagnosis [18]. Previous reports demonstrated that $25-30 \%$ of children with IBD had a deficit in final height $[19,20]$. Although pediatric $\mathrm{CD}$ patients have normal growth hormone $(\mathrm{GH})$ concentrations, low serum insulin-like growth factor-1 (IGF-1) levels caused by malnutrition and elevated proinflammatory cytokine levels contribute to growth impairment [11, 21]. Cytokines may interfere with GH and IGF-1 action and have direct effects on growth plates, rendering the growth plates less sensitive to IGF-1 [22]. Delayed puberty is also frequently found in patients with IBD $[10,18]$. It is presumed that puberty is delayed due to abnormalities of sex steroid production or action caused by proinflammatory cytokines [10, 23]. Pro-inflammatory cytokines may inhibit the generation of sex hormones by acting on the gonads or by suppressing gonadotropin-releasing hormone $(\mathrm{GnRH})[24,25]$. The timing of breast development, testicular enlargement, growth spurt, and menarche are also delayed in patients with IBD $[18,26,27]$. In addition, about $41.4-46.7 \%$ of children and adolescents with IBD showed low BMD with a Z-score $\leq-1.0[13,28]$. Risk factors of reduced BMD include glucocorticoid treatment, nutritional deficiencies of vitamin $\mathrm{D}$ and/or calcium, hypogonadism, and diseaserelated chronic inflammation [29].

As the number of children and adolescents diagnosed with IBD has gradually increased, careful documentation of endocrine complications in children and adolescents with IBD is critical for management. A comprehensive understanding of endocrine complications and multidisciplinary approach to IBD patients make it possible to provide better treatment and clinical outcome as well as management of gastrointestinal symptoms. To date, a few studies have focused on the analysis of endocrine complications of pediatric IBD in a limited number of cases [16, 3032]. However, the pathogenesis, frequency, and outcomes of endocrine complications of IBD have not been fully established. Thus, this study was performed to investigate the frequency, clinical characteristics, and outcomes of endocrine complications in children and adolescents with IBD.

\section{Methods/design Subjects}

This study retrospectively reviewed medical records of 127 patients who were diagnosed with IBD before 18 years of age and visited pediatric endocrinologic outpatient clinic between January 2005 and December 2017. Among the 127 patients, 117 patients were diagnosed with $\mathrm{CD}$, and 10 patients were diagnosed with UC. All patients were followed up for at least two years. Diagnosis of IBD was based on clinical, radiologic, endoscopic, and histologic findings [33, 34]. Disease activity indices of $\mathrm{CD}$ using the pediatric $\mathrm{CD}$ activity index (PCDAI) were calculated by evaluating categories such as history items, physical examination items, and laboratory tests. Items were scored and PCDAI is the sum of all scores of each category (range: 0-100) [35]. Patients with CD were categorized into two groups according to PCDAI scoring: < 30 as inactive/mild and $\geq 30$ as moderate/severe CD [36]. This study was approved by the Institutional Review Board of the Asan Medical Center, Seoul, Korea (IRB No. 2017 -0939). Our study was exempt from the requirement of informed consent because of the retrospective nature of the study and the analysis used anonymous clinical data.

\section{Endocrinologic evaluation}

Growth parameters including height, weight, body mass index (BMI, $\left.\mathrm{kg} / \mathrm{m}^{2}\right)$, serum IGF-1, and IGF binding protein-3 (IGFBP-3), were reviewed. Height, weight, and BMI were expressed using standard deviation scores (SDSs) based on age- and sex-matched normative data from Korean references [37]. Serum IGF-1 and IGFBP-3 levels were measured using an immunoradiometric assay (IRMA, Immunotech, Marseilles, France) and were 
expressed as a SDS based on age- and sex-matched normative data from Korean references [38]. Puberty was assessed by the following parameters: Tanner stage; bone age (BA); and serum luteinizing hormone (LH), follicle stimulating hormone (FSH), estradiol (in females), and testosterone levels (in males). The LH and FSH levels were determined by immunoradiometric assay (IRMAmat, Byk-Sangtec Diagnostica, Hessen, Germany). The estradiol and testosterone levels were measured by radioimmunoassay (Coat-A-Count, Diagnostic Products, Los Angeles, CA, USA). BA was determined by the Greulich-Pyle method [39]. BMD of the lumbar spine (L2-4) was measured by dual energy X-ray absorptiometry (DXA, Lunar Corp., Madison, WI, USA). BMD $\mathrm{Z}$-score was adjusted using age- and sex-matched references for Korean children [40, 41]. Since Korean reference data was measured by the Hologic system, BMD data was converted using following formula: Hologic lumbar spine $\mathrm{BMD}=0.837 \times \mathrm{GE}$-Lunar lumbar spine $\mathrm{BMD}+0.021[42]$.

Short stature was defined as a height-SDS of less than -2.0 according to age- and sex-matched Korean references [37]. Delayed puberty was defined as the absence of secondary sexual characteristics at age 14 years for males and 13 years for females [43]. Serum thyroid stimulating hormone (TSH) level was measured using an immunoradiometric assay (TSHCTK $-3^{\circ}$, DiaSorin, Saluggia, Italy). Serum free T4 level was determined by a radioimmunoassay (FT4 RIA $\mathrm{Kit}^{\circ}$, Beckman Coulter, Prague, Czech Republic). Vitamin $\mathrm{D}$ deficiency was defined as a $25(\mathrm{OH}) \mathrm{D}_{3}$ level less than $20 \mathrm{ng} / \mathrm{mL}$ [44]. The $25(\mathrm{OH}) \mathrm{D}_{3}$ level was measured using radioimmunoassay (Nichols Institute Diagnostics, San Clemente, CA, USA). Osteoporosis was defined as a BMD Z-score less than -2.0 by measuring lumbar spine 2 to 4 [45].

\section{Statistical analyses}

Statistical analyses were performed using IBM SPSS Statistics for Windows version 21.0 (IBM Corp., Armonk, NY, USA). To evaluate endocrine complications between two groups categorized by PCDAI scores, continuous variables such as anthropometric and biochemical data were analyzed by independent $t$-tests, while discrete variables such as presence of short stature, delayed puberty, vitamin $\mathrm{D}$ deficiency, and osteoporosis were analyzed by Fisher's exact test. Mann-Whitney $U$ test was used to compare anthropometric data between two groups classified according to the presence of delayed puberty because only 11 patients manifested delayed puberty. The independent $t$ test was used to compare anthropometric and biochemical data of groups categorized according to the presence of osteoporosis. Pearson correlation analysis was used to assess the correlation between serum $25(\mathrm{OH}) \mathrm{D}_{3}$ level and lumbar spine BMD Z-score. $P$ values $<0.05$ were considered statistically significant.

\section{Results}

Growth impairment in patients with IBD

Age at time of diagnosis of included patients with IBD was $13.5 \pm 2.5$ years (range, 1.3-17.8 years). Initial height-SDS and weight-SDS were $-0.39 \pm 1.06$ and $1.19 \pm 1.38$, respectively. Initial BMI-SDS was $-1.26 \pm$ 1.40. Demographic data and clinical characteristics of the patients are described in Table 1.

Short stature was observed in 14 of 127 patients $(11.0 \%)$ including 13 patients with $\mathrm{CD}$ and one patient with UC. The average age at time of diagnosis of IBD in patients with short stature was $11.9 \pm 3.6$ years, and the mean age at time of IBD diagnosis in patients without short stature was $13.7 \pm 2.3$ years. The mean height-SDS and weight-SDS in 14 patients with short stature at time of diagnosis were $-2.31 \pm 0.72$ and $-2.34 \pm 1.47$,

Table 1 Demographic and clinical characteristics of the patients at diagnosis

\begin{tabular}{llll}
\hline & CD $(\boldsymbol{n}=\mathbf{1 1 7})$ & UC $(\boldsymbol{n}=\mathbf{1 0})$ & Total $(\boldsymbol{n}=\mathbf{1 2 7})$ \\
\hline Sex (male/female) & $79 / 38$ & $5 / 5$ & $84 / 43$ \\
Age at diagnosis, years & $13.5 \pm 2.3(2.0-17.8)$ & $12.8 \pm 4.5(1.3-16.6)$ & $13.5 \pm 2.5(1.3-17.8)$ \\
Height-SDS & $-0.42 \pm 1.08$ & $-0.01 \pm 0.83$ & $-0.39 \pm 1.06$ \\
Weight-SDS & $-1.23 \pm 1.39$ & $-0.55 \pm 1.14$ & $-1.19 \pm 1.38$ \\
BMI-SDS & $-1.30 \pm 1.41$ & $-0.67 \pm 1.22$ & $-1.26 \pm 1.40$ \\
Short stature & $13 / 117$ & $1 / 10$ & $14 / 127(11.0 \%)$ \\
Delayed puberty & $11 / 101$ & $0 / 8$ & $11 / 109(10.1 \%)$ \\
Vitamin D deficiency & $87 / 106$ & $7 / 9$ & $94 / 115(81.7 \%)$ \\
25(OH)D $D_{3}$ ng/mL & $14.55 \pm 7.04(2.2-45.2)$ & $13.69 \pm 5.85(7.1-22.1)$ & $14.49 \pm 6.94(2.2-45.2)$ \\
Osteoporosis & $21 / 111$ & $4 / 8$ & $25 / 119(21.0 \%)$ \\
Lumbar spine BMD-SDS & $-0.82 \pm 1.29(-4.07-4.36)$ & $-0.61 \pm 1.53(-2.11-2.16)$ & $-0.80 \pm 1.31(-4.07-4.36)$
\end{tabular}

$C D$ Crohn disease, UC Ulcerative colitis, $B M I$ body mass index, $25(\mathrm{OH}) \mathrm{D}_{3}$ 25-hydroxyvitamin $\mathrm{D}_{3}, B M D$ Bone mineral density 
respectively. The BMI-SDS in the 14 patients with short stature was $-1.50 \pm 1.46$, which was not significantly different from the mean BMI $(-1.22 \pm 1.40)$ of the patients without short stature $(P=0.415)$. The $\mathrm{BA} /$ chronological age (CA) ratio of patients with short stature was $1.04 \pm$ 0.11 . Mid-parental height (MPH)-SDS in patients with short stature was $-0.57 \pm 0.52$.

PCDAI scores were assessed in 88 patients with CD whose clinical information was available. They were classified into two groups according to PCDAI scores [inactive/mild $(n=41) \quad$ vs. moderate/severe $(n=47)]$. Patients in the moderate/severe group (PCDAI score $\geq$ 30) had lower weight-SDS, BMI-SDS, and IGF-1 SDS than the patients in the inactive/mild group (all $P<$ 0.001) (Table 2).

During a 2-year follow-up period, height-SDS and weight-SDS data were available in 70 patients. Nineteen of 70 patients had a height velocity of less than $2 \mathrm{~cm}$ over 2 years. Among the remaining 51 patients, heightSDS did not significantly improved $(P=0.958)$, while weight-SDS was significantly increased $(P<0.001)$ (Fig. 1). The mean age at diagnosis of IBD was $13.5 \pm$ 1.6 years (range, 9.5-15.9 years) in 33 boys and 11.6 \pm 3.2 years (1.3-15.5 years) in 18 girls. Weight gain mainly occurred during the first 6 months after treatment. In 14 patients with short stature, significant improvement was not observed in weight-SDS as well as height-SDS.

\section{Delayed puberty in patients with IBD}

Thirty-six girls were above the age of 13 years, and 73 boys were above the age of 14 years at the time of their last follow-up. Among 109 patients (36 girls and 73 boys, $101 \mathrm{CD}$ and $8 \mathrm{UC}$ ), 11 patients (6 boys and 5 girls) with $\mathrm{CD}(10.1 \%)$ had delayed puberty. The mean age at diagnosis of IBD in the 11 patients was $14.3 \pm 1.4$ years. The mean BA/CA ratio in patients with delayed puberty was $0.84 \pm 0.10$ (range, 0.73-0.91). Initial height-SDS and weight-SDS at diagnosis of IBD were $-1.94 \pm 1.26$ and $3.32 \pm 1.90$, respectively. The mean initial height- and weight-SDS at diagnosis of IBD in patients without delayed puberty were $-0.28 \pm 0.96$ and $-1.03 \pm 1.20$, respectively, which were significantly higher than the height-SDS and weight-SDS of patients with delayed puberty $(P=0.001$ and 0.001 , respectively). The mean BMI-SDS of the patients with delayed puberty was significantly lower than the BMI-SDS of the patients without delayed puberty $(-2.77 \pm 1.77$ vs. $-1.15 \pm 1.31$, $P=0.010)$. Patients in the moderate/severe group (PCDAI score $\geq 30$ ) had significantly lower testosterone

Table 2 Clinical and biochemical parameters according to PCDAI scores

\begin{tabular}{|c|c|c|c|}
\hline & $\begin{array}{l}\text { PCDAI }<30 \\
\text { Inactive/mild }(n=41)\end{array}$ & $\begin{array}{l}\mathrm{PCDAI} \geq 30 \\
\text { Moderate/Severe }(n=47)\end{array}$ & $P$ value \\
\hline Age at diagnosis, years & $13.5 \pm 1.9$ & $13.6 \pm 2.7$ & 0.934 \\
\hline Sex (Male:Female) & $32: 9$ & $28: 19$ & \\
\hline PCDAl score & $15.85 \pm 7.96$ & $45.80 \pm 11.23$ & $<0.001$ \\
\hline Short stature & $4 / 41$ & $3 / 47$ & 0.700 \\
\hline Height-SDS & $-0.18 \pm 1.08$ & $-0.50 \pm 0.97$ & 0.156 \\
\hline Weight-SDS & $-0.50 \pm 1.17$ & $-1.69 \pm 1.32$ & $<0.001$ \\
\hline BMI-SDS & $-0.56 \pm 1.31$ & $-1.79 \pm 1.30$ & $<0.001$ \\
\hline IGF-1 SDS & $-0.35 \pm 1.30$ & $-1.96 \pm 1.17$ & $<0.001$ \\
\hline IGFBP-3 SDS & $-1.48 \pm 1.31$ & $-4.63 \pm 18.41$ & 0.577 \\
\hline $\mathrm{BA} / \mathrm{CA}$ ratio & $0.85 \pm 0.11$ & $1.01 \pm 0.11$ & 0.034 \\
\hline Delayed puberty & $3 / 41$ & $3 / 47$ & 1.000 \\
\hline LH, IU/L & $2.88 \pm 1.28$ & $2.16 \pm 1.66$ & 0.104 \\
\hline FSH, IU/L & $3.01 \pm 1.51$ & $2.12 \pm 1.48$ & 0.416 \\
\hline Estradiol, pg/mL (Female) & $12.99 \pm 3.19$ & $15.21 \pm 8.99$ & 0.473 \\
\hline Testosterone, ng/mL (Male) & $2.70 \pm 2.14$ & $1.32 \pm 1.53$ & 0.034 \\
\hline $\mathrm{TSH}, \mu \mathrm{IU} / \mathrm{mL}$ & $2.12 \pm 1.11$ & $2.02 \pm 1.32$ & 0.784 \\
\hline Free $\mathrm{T4}, \mathrm{ng} / \mathrm{dL}$ & $1.28 \pm 0.13$ & $1.41 \pm 0.20$ & 0.010 \\
\hline $25(\mathrm{OH}) \mathrm{D}_{3}, \mathrm{ng} / \mathrm{mL}$ & $14.23 \pm 6.77$ & $15.97 \pm 6.52$ & 0.253 \\
\hline Osteoporosis & $7 / 38$ & $9 / 46$ & 0.813 \\
\hline Lumbar BMD Z-score & $-0.55 \pm 1.39$ & $-0.84 \pm 1.31$ & 0.321 \\
\hline
\end{tabular}

PCDAI Pediatric Crohn disease activity index, IGF-1 Insulin-like growth factor-1, IGFBP-3 Insulin-like growth factor binding protein-3, BA Bone age, CA Chronological age, $L H$ Luteinizing hormone, FSH Follicle stimulating hormone, $T S H$ Thyroid stimulating hormone, $25(\mathrm{OH}) \mathrm{D}_{3} 25$-hydroxyvitamin $\mathrm{D}_{3}$ 


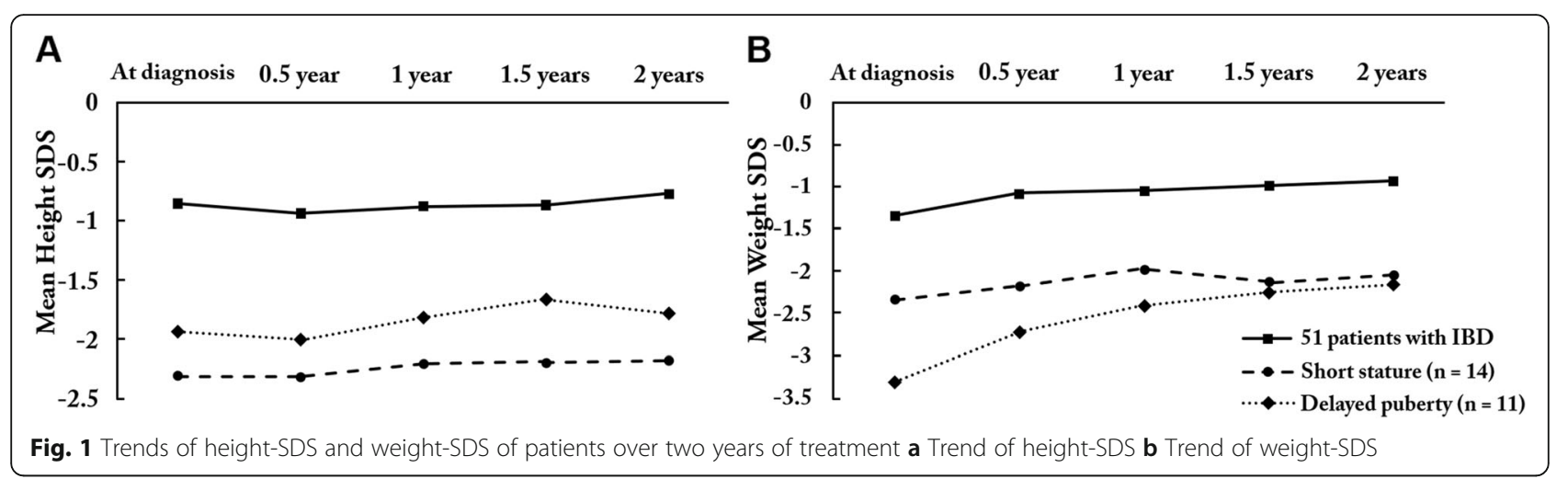

concentrations than patients in the inactive/mild group $(P=0.034)$.

Among 5 girls with delayed puberty, one girl manifested menarche at 16 years of age; however, menstruation was no longer observed after her first menstrual period. Another girl showed menarche at the age of 15.5 years. The other 3 girls did not experience menarche by the time of the last follow-up (age, 14.115.8 years).

Among 31 patients who showed spontaneous menarche, 8 girls $(25.8 \%)$ manifested secondary amenorrhea at diagnosis of IBD at a mean age of $15.1 \pm 0.8$ years. Serum LH, FSH, and estradiol levels of the 8 girls with secondary amenorrhea were $1.78 \pm 0.73 \mathrm{IU} / \mathrm{L}, 4.49 \pm$ $3.19 \mathrm{IU} / \mathrm{L}$, and $13.59 \pm 4.17 \mathrm{pg} / \mathrm{mL}$, respectively.

\section{Vitamin $\mathrm{D}$ deficiency and bone mineral density}

Serum $25(\mathrm{OH}) \mathrm{D}_{3}$ levels were measured in 115 of 127 patients. The mean $25(\mathrm{OH}) \mathrm{D}_{3}$ level was $14.5 \pm 6.9 \mathrm{ng} /$ $\mathrm{mL}$ (range, $2.2-45.2 \mathrm{ng} / \mathrm{mL}$ ) (Table 1). Vitamin D deficiency was documented in $81.7 \%(94 / 115)$ of patients (87 patients with $\mathrm{CD}[82.1 \%, 87 / 106]$ and 7 children with UC $[77.8 \%, 7 / 9])$. Among 94 patients with vitamin D deficiency, 21 patients (22.3\%) had lumbar BMD Zscores lower than -2 SDS.

DXA was performed in 119 patients at the time of IBD diagnosis. BMD Z-score was below - 1.0 in 60 of 119 patients $(50.4 \%)$. Twenty-five of 119 patients $(21.0 \%)$ had BMD Z-scores below - 2.0 (21 patients with CD and 4 patients with UC). In 25 patients with osteoporosis (BMD Z-score $\leq-2.0)$, the mean BMD Z-score was $2.34 \pm 0.93$, and the mean serum $25(\mathrm{OH}) \mathrm{D}_{3}$ level was $14.01 \pm 5.71 \mathrm{ng} / \mathrm{mL}$ (Table 3).

Height-SDS, weight-SDS, and BMI-SDS at diagnosis of IBD were lower in patients with osteoporosis than in patients without osteoporosis $(P<0.001, P<0.001, P=$ 0.009 , respectively). Serum $25(\mathrm{OH}) \mathrm{D}_{3}$ level positively correlated with lumbar BMD Z-score by Pearson correlation analysis $(r=0.215, P=0.024)$. Lumbar BMD Z- scores were lower in patients with delayed puberty than that in patients without delayed puberty $(-2.42 \pm 1.30$ vs. $-0.60 \pm 1.23, P<0.001)$.

Four patients with osteoporosis were treated with pamidronate for $20.0 \pm 7.0$ months (range, 1228 months). Three patients who were treated with pamidronate therapy showed their average lumbar BMD Z-scores before and after pamidronate therapy were $2.93 \pm 0.29$ and $-1.48 \pm 0.56$, respectively $(P=0.109)$. Follow-up lumbar BMD in these three patients was measured at 12 to 18 months after pamidronate therapy. In one patient whose lumbar BMD Z-score did not improve after pamidronate therapy, lumbar BMD Z-scores decreased from -3.64 to -3.76 . This patient was diagnosed with $C D$ at the age of 11.4 years, and her heightSDS and weight-SDS at diagnosis of CD were -1.47 and -2.62 , respectively. Her lumbar BMD was evaluated the age of 13.4, 14.4, and 15.4 years because she did not present pubertal signs until she reached 15.4 years of age. Her lumbar BMD Z-scores were - 2.16, -3.23, and -3.64 at the age of $13.4,14.4$, and 15.4 years, respectively.

\section{Discussion}

This study evaluated the frequency and outcomes of endocrine complications in children and adolescents with IBD. PCDAI scores were negatively correlated with weight-, BMI-, and IGF-1-SDS, and testosterone level. In addition, low weight-SDS was associated with delayed puberty, and optimal pubertal development was necessary for appropriate BMD in patients with IBD. Thus, clinical severity of IBD is critical to the growth, pubertal development, and bone health of children and adolescents with IBD.

In the present study, $11.0 \%$ of the patients manifested short stature. Growth retardation is more common in $\mathrm{CD}$, because the insidious onset and failure of linear growth are associated with small bowel involvement [22, $46,47]$. Thus, small numbers of patients with UC were referred to our endocrine clinic and enrolled in this 
Table 3 Clinical and biochemical parameters according to the presence of osteoporosis

\begin{tabular}{|c|c|c|c|}
\hline & Spine BMD $\leq-2$ SDS $(n=25)$ & Spine BMD > -2 SDS $(n=94)$ & $P$ value \\
\hline Sex (male:female) & $13: 12$ & $66: 28$ & \\
\hline Age at diagnosis, years & $14.3 \pm 1.5$ & $13.5 \pm 2.1$ & 0.057 \\
\hline PCDAl & $36.56 \pm 20.16$ & $31.82 \pm 17.80$ & 0.410 \\
\hline Delayed puberty & $8 / 25$ & $3 / 94$ & $<0.001$ \\
\hline Height-SDS at diagnosis & $-1.47 \pm 1.11$ & $-0.11 \pm 0.90$ & $<0.001$ \\
\hline Weight-SDS at diagnosis & $-2.40 \pm 1.45$ & $-0.99 \pm 1.23$ & $<0.001$ \\
\hline BMI-SDS at diagnosis & $-2.07 \pm 1.36$ & $-1.19 \pm 1.35$ & 0.009 \\
\hline Calcium, mg/dL & $8.67 \pm 0.57$ & $8.94 \pm 0.46$ & 0.082 \\
\hline Phosphorus, mg/dL & $5.07 \pm 0.53$ & $4.28 \pm 0.75$ & 0.053 \\
\hline Alkaline phosphatase, IU/L & $111.56 \pm 38.04$ & $124.65 \pm 46.64$ & 0.268 \\
\hline IGF-1 SDS & $-1.50 \pm 1.46$ & $-1.00 \pm 1.21$ & 0.169 \\
\hline IGFBP-3 SDS & $-6.64 \pm 21.53$ & $-1.21 \pm 1.21$ & 0.102 \\
\hline $\mathrm{TSH}, \mu \mathrm{IU} / \mathrm{mL}$ & $2.40 \pm 1.25$ & $2.04 \pm 1.39$ & 0.222 \\
\hline Free $T 4, \mathrm{ng} / \mathrm{dL}$ & $1.37 \pm 0.15$ & $1.40 \pm 0.20$ & 0.608 \\
\hline LH, IU/L & $2.19 \pm 2.04$ & $2.71 \pm 1.58$ & 0.088 \\
\hline FSH, IU/L & $4.18 \pm 2.79$ & $2.90 \pm 2.04$ & 0.098 \\
\hline Estradiol, pg/mL & $17.34 \pm 11.35$ & $12.93 \pm 3.81$ & 0.657 \\
\hline Testosterone, ng/mL & $1.71 \pm 1.69$ & $2.54 \pm 2.16$ & 0.323 \\
\hline $25(\mathrm{OH}) \mathrm{D}_{3}, \mathrm{ng} / \mathrm{mL}$ & $14.01 \pm 5.71$ & $14.26 \pm 6.52$ & 0.874 \\
\hline Lumbar BMD Z-score & $-2.34 \pm 0.93$ & $-0.39 \pm 1.07$ & $<0.001$ \\
\hline
\end{tabular}

BMD Bone mineral density, PCDAI Pediatric Crohn disease activity index, BMI Body mass index, IGF-1 Insulin-like growth factor-1, IGFBP-3 Insulin-like growth factor binding protein-3, TSH Thyroid stimulating hormone, $\mathrm{LH}$ Luteinizing hormone, FSH Follicle stimulating hormone, 25(OH) $D_{3} 25$-hydroxyvitamin $\mathrm{D}_{3}$

study. The prevalence and severity of growth impairment has differed among several previous studies [18, 48]. Growth failure can be described in terms of height-SDS or by variations in growth velocity during $3-4$ months [48]. A previous study reported that height Z-scores $\leq-2 \mathrm{SD}$ were seen in $19 \%$ of patients with CD and $5 \%$ of UC patients [49]. However, decreased height velocity was observed in $65 \%$ of CD and $34 \%$ of UC patients [19]. In the present study, 14 out of 127 patients presented with short stature (height Z-scores $\leq-2 \mathrm{SD}$ ). We could not investigate height velocity before diagnosis of IBD since this study was a retrospective review of medical records, and some data were not available.

Factors that negatively affect linear growth are increased levels of inflammatory cytokines such as interleukin-6 (IL-6) and tumor necrosis factor- $\alpha$ (TNF$\alpha$ ), malnutrition, suppression of serum IGF-1 levels, and disease severity [11, 50,51]. Our study showed lower IGF-1-SDSs in patients with higher PCDAI scores $(\geq 30)$, indicating that linear growth was influenced by severity of IBD. Given that growth problems are due to inflammation and undernutrition, catch-up growth after treatment could occur [52]. Our patients did not present significant height-SDS improvement during the followup period, while weight-SDS significantly improved. It is thought that significant changes in height-SDS were not shown in patients whose pubertal spurt was attenuated and in cases diagnosed with IBD in late puberty. In the previous study, catch-up growth did not occur due to an attenuated pubertal growth spurt, although they show secondary sexual characteristics within the average pubertal age range [14]. Thus, early diagnosis and intervention are critical for better outcomes from the perspective of growth. Delayed diagnosis of IBD has been found to affect the degree of growth impairment $[47,53,54]$.

Inflammation and poor nutrition also affect pubertal development. Our study showed lower testosterone levels in patients with higher PCDAI scores $(\geq 30)$. Increased pro-inflammatory cytokine levels have been associated with reduced serum testosterone levels, which results in delayed puberty [10]. Thus, delayed puberty is more common in patients who have not achieved remission or have active disease [10]. In our study, 10.1\% (11 out of 109) of patients presented with delayed puberty, and they showed significantly low BMI. Another 8 out of 31 who experienced menarche before diagnosis of IBD showed secondary amenorrhea. The relationship between the IBD and menstrual alteration has not been completely explored. Aberration of the pulsatile release of GnRH from the hypothalamus leads to cessation of menstruation, which could occur in response to weight loss [55]. Pubertal delay also contributes to growth 
retardation. Therefore, early management of disease activity and maintaining remission is essential for optimal growth and pubertal development.

In our study, vitamin $\mathrm{D}$ deficiency was documented in $81.7 \%(94 / 115)$ of patients. Vitamin D deficiency is present in $57-62 \%$ of pediatric IBD patients $[56,57]$. Frequency of vitamin $\mathrm{D}$ deficiency can be different according to the different cut off level of $25(\mathrm{OH}) \mathrm{D}_{3}(<$ $12 \mathrm{ng} / \mathrm{mL}$ ) [58]. Disease severity can affect vitamin D intake or absorption and bile salt absorption, leading to excessive losses of dietary vitamin D [59]. In addition, it has been suggested that vitamin $\mathrm{D}$ deficiency might be a contributing factor in the development of IBD, as vitamin D plays a role in affecting anti-inflammatory adaptive immune function of the gastrointestinal tract $[60$, 61]. Thus, it is essential to check serum vitamin D levels and supplement vitamin D in patients with IBD.

In the present study, vitamin $\mathrm{D}$ levels positively correlated with lumbar spine BMD. There have been some conflicting reports as to whether vitamin D deficiency is a risk factor for low BMD $[62,63]$. In a recent study of Asian children, female sex, older age, and low hemoglobin levels further increase risk of low BMD Zscores rather than vitamin $\mathrm{D}$ status in patients with IBD [31]. As for BMD in our study, delayed puberty was more commonly found in patients with osteoporosis, suggesting that timely pubertal development is critical for bone mass accrual. Disease-related chronic inflammation and glucocorticoid treatment are also implicated in impaired bone metabolism. Regarding the recovery of decreased BMD, a recent study showed promising result where bone formation markers such as bone alkaline phosphatase and osteocalcin were increased after treatment using an anti-TNF agent [64]. However, improvement in bone turnover markers has not led to an increase in BMD Z-score [13, 28]. The risk of fracture in pediatric IBD was not higher than age-, sex-, and gender-matched controls in a previous study [65]. In contrast to pediatric patients, adults with IBD are at increased risk of hip fracture, suggesting that regular BMD examination is needed in IBD patients [66].

This study is limited by its reliance on anthropometric data, laboratory findings, and DXA information from medical records, and some records were not available.

\section{Conclusions}

This study demonstrated that vitamin D deficiency and low BMD were the common endocrine complications in children and adolescents with IBD. Clinical severity of IBD is critical to the growth, pubertal development, and bone health of children and adolescents with IBD. Regular assessment of growth parameters, pubertal stage, and BMD is necessary in children and adolescents with IBD for adequate growth and bone health.

\section{Abbreviations}

BMD: Bone mineral density; IBD: Inflammatory bowel disease; CD: Crohn disease; UC: Ulcerative colitis; $25(\mathrm{OH}) \mathrm{D}_{3}$ : 25 -hydroxyvitamin $\mathrm{D}_{3}$; SDS: Standard deviation score; BMI: Body mass index; IGF-1: Insulin-like growth factor-1; GH: Growth hormone; PCDAl: Pediatric Crohn disease activity index; IGFBP3: Insulin-like growth factor binding protein-3; BA: Bone age; LH: Luteinizing hormone; FSH: Follicle stimulating hormone; DXA: Dual energy X-ray absorptiometry; CA: Chronological age; TSH: Thyroid stimulating hormone; IL6: Interleukin-6; TNF-a: Tumor necrosis factor-a; GnRH: Gonadotropinreleasing hormone

\section{Acknowledgements}

Not applicable.

\section{Authors' contributions}

$\mathrm{HYJ}$ and JHC designed the study and wrote the manuscript; JSL collected the data and involved in data analysis; YL, YC, SHO, KMK, and HWY collected the data and made contributions to the draft. All the authors made final corrections and approved the manuscript.

\section{Funding}

This study was financially supported by the Basic Science Research Program through the National Research Foundation of Korea (NRF) funded by the Ministry of Education (2017R1D1A1B03029638). The funders had no role in the study design, data collection, analysis of data, or writing the manuscript, but provided funding for open access publishing.

\section{Availability of data and materials}

The datasets used and/or analyzed during the current study are available from the corresponding author on reasonable request.

\section{Ethics approval and consent to participate}

This study was approved by the Institutional Review Board of the Asan Medical Center, Seoul, Korea (IRB No. 2017 - 0939). Our study was exempt from the requirement of informed consent because of the retrospective nature of the study and the analysis used anonymous clinical data.

\section{Consent for publication}

Not applicable.

\section{Competing interests}

The authors declare that they have no competing interests.

\section{Author details}

${ }^{1}$ Department of Pediatrics, Center for Pediatric Cancer, National Cancer Center, Goyang, Gyeonggi-do, Republic of Korea. ${ }^{2}$ Department of Pediatrics, Asan Medical Center, University of Ulsan College of Medicine, 88, Olympic-Ro 43-Gil, Songpa-Gu, 05505 Seoul, Republic of Korea.

Received: 19 August 2020 Accepted: 7 January 2021

Published online: 14 January 2021

\section{References}

1. Xavier RJ, Podolsky DK. Unravelling the pathogenesis of inflammatory bowel disease. Nature. 2007:448(7152):427-34.

2. Ng SC, Shi HY, Hamidi N, Underwood FE, Tang W, Benchimol El, Panaccione R, Ghosh S, Wu JCY, Chan FKL, et al. Worldwide incidence and prevalence of inflammatory bowel disease in the 21st century: a systematic review of population-based studies. Lancet. 2018;390(10114):2769-78.

3. Ng SC, Tang W, Ching JY, Wong M, Chow CM, Hui AJ, Wong TC, Leung VK, Tsang SW, Yu HH, et al. Incidence and phenotype of inflammatory bowel disease based on results from the Asia-pacific Crohn's and colitis epidemiology study. Gastroenterology. 2013;145(1):158-65 e152.

4. Gasparetto M, Guariso G. Highlights in IBD Epidemiology and Its Natural History in the Paediatric Age. Gastroenterol Res Pract. 2013;2013:829040.

5. Molodecky NA, Soon IS, Rabi DM, Ghali WA, Ferris M, Chernoff G, Benchimol El, Panaccione R, Ghosh S, Barkema HW, et al. Increasing incidence and prevalence of the inflammatory bowel diseases with time, based on systematic review. Gastroenterology. 2012;142(1):46-54. e42; quiz e30.

6. Kwak MS, Cha JM, Lee HH, Choi YS, Seo SI, Ko KJ, Park DI, Kim SH, Kim TJ. Emerging trends of inflammatory bowel disease in South Korea: A 
nationwide population-based study. J Gastroenterol Hepatol. 2019;34(6): 1018-26.

7. Abraham BP, Mehta S, El-Serag HB. Natural history of pediatric-onset inflammatory bowel disease: a systematic review. J Clin Gastroenterol. 2012: 46(7):581-9.

8. Sykora J, Pomahacova R, Kreslova M, Cvalinova D, Stych P, Schwarz J. Current global trends in the incidence of pediatric-onset inflammatory bowel disease. World J Gastroenterol. 2018;24(25):2741-63.

9. Hong SJ, Cho SM, Choe BH, Jang HJ, Choi KH, Kang B, Kim JE, Hwang JH. Characteristics and Incidence Trends for Pediatric Inflammatory Bowe Disease in Daegu-Kyungpook Province in Korea: a Multi-Center Study. J Korean Med Sci. 2018;33(18):e132.

10. Ballinger $A B$, Savage $M O$, Sanderson IR. Delayed puberty associated with inflammatory bowel disease. Pediatr Res. 2003;53(2):205-10.

11. Wong SC, Smyth A, McNeill E, Galloway PJ, Hassan K, McGrogan P, Ahmed SF. The growth hormone insulin-like growth factor 1 axis in children and adolescents with inflammatory bowel disease and growth retardation. Clin Endocrinol. 2010;73(2):220-8.

12. Lee JJ, Escher JC, Shuman MJ, Forbes PW, Delemarre LC, Harr BW, Kruijer M, Moret M, Allende-Richter S, Grand RJ. Final adult height of children with inflammatory bowel disease is predicted by parental height and patient minimum height Z-score. Inflamm Bowel Dis. 2010;16(10):1669-77.

13. Schmidt S, Mellstrom D, Norjavaara E, Sundh SV, Saalman R. Low bone mineral density in children and adolescents with inflammatory bowel disease: a population-based study from Western Sweden. Inflamm Bowel Dis. 2009;15(12):1844-50.

14. Mason A, Malik S, McMillan M, McNeilly JD, Bishop J, McGrogan P, Russell RK, Ahmed SF. A prospective longitudinal study of growth and pubertal progress in adolescents with inflammatory bowel disease. Horm Res Paediatr. 2015;83(1):45-54.

15. Ezri J, Marques-Vidal P, Nydegger A. Impact of disease and treatments on growth and puberty of pediatric patients with inflammatory bowel disease. Digestion. 2012;85(4):308-19.

16. Song SM, Kim Y, Oh SH, Kim KM. Nutritional status and growth in Korean children with Crohn's disease: a single-center study. Gut Liver. 2014;8(5): 500-7.

17. Kanof ME, Lake AM, Bayless TM. Decreased height velocity in children and adolescents before the diagnosis of Crohn's disease. Gastroenterology. 1988 ; 95(6):1523-7.

18. DeBoer MD, Denson LA. Delays in puberty, growth, and accrual of bone mineral density in pediatric Crohn's disease: despite temporal changes in disease severity, the need for monitoring remains. J Pediatr. 2013;163(1):17-22

19. Hildebrand $\mathrm{H}$, Karlberg J, Kristiansson B. Longitudinal growth in children and adolescents with inflammatory bowel disease. J Pediatr Gastroenterol Nutr. 1994;18(2):165-73.

20. Motil KJ, Grand RJ, Davis-Kraft L, Ferlic LL, Smith EO. Growth failure in children with inflammatory bowel disease: a prospective study. Gastroenterology. 1993;105(3):681-91.

21. Shamir R, Phillip M, Levine A. Growth retardation in pediatric Crohn's disease: pathogenesis and interventions. Inflamm Bowel Dis. 2007;13(5): 620-8.

22. Sanderson IR. Growth problems in children with IBD. Nat Rev Gastroenterol Hepatol. 2014;11(10):601-10.

23. Morales V, Santana P, Diaz R, Tabraue C, Gallardo G, Lopez Blanco F, Hernandez I, Fanjul LF, Ruiz de Galarreta CM. Intratesticular delivery of tumor necrosis factor-alpha and ceramide directly abrogates steroidogenic acute regulatory protein expression and Leydig cell steroidogenesis in adult rats. Endocrinology. 2003;144(11):4763-72.

24. Hong CY, Park JH, Ahn RS, Im SY, Choi HS, Soh J, Mellon SH, Lee K. Molecular mechanism of suppression of testicular steroidogenesis by proinflammatory cytokine tumor necrosis factor alpha. Mol Cell Biol. 2004; 24(7):2593-604.

25. Rettori V, Belova N, Kamat A, Lyson K, Gimeno M, McCann SM. Blockade by interleukin-1-alpha of nitricoxidergic control of luteinizing hormonereleasing hormone release in vivo and in vitro. Neuroimmunomodulation. 1994;1(1):86-91.

26. Gupta N, Lustig RH, Kohn MA, Vittinghoff E. Menarche in pediatric patients with Crohn's disease. Dig Dis Sci. 2012;57(11):2975-81.

27. Brain CE, Savage MO. Growth and puberty in chronic inflammatory bowel disease. Baillieres Clin Gastroenterol. 1994;8(1):83-100.
28. Sylvester FA, Wyzga N, Hyams JS, Davis PM, Lerer T, Vance K, Hawker G, Griffiths AM. Natural history of bone metabolism and bone mineral density in children with inflammatory bowel disease. Inflamm Bowel Dis. 2007;13(1):42-50

29. Tigas S, Tsatsoulis A. Endocrine and metabolic manifestations in inflammatory bowel disease. Ann Gastroenterol. 2012;25(1):37-44.

30. Kim S, Kang Y, Park S, Koh H, Kim S. Association of Vitamin D with Inflammatory Bowel Disease Activity in Pediatric Patients. J Korean Med Sci. 2019;34(32):e204.

31. Sohn J, Chang EJ, Yang HR. Vitamin D Status and Bone Mineral Density in Children with Inflammatory Bowel Disease Compared to Those with Functional Abdominal Pain. J Korean Med Sci. 2017;32(6):961-7.

32. Lee EJ, Moon JS, Ko JS, Yang HR, Jang JY, Kim JW, Lee KJ. Effect of the Baseline Vitamin D Level on Growth Outcome in Pediatric Crohn Disease. Pediatr Gastroenterol Hepatol Nutr. 2017:20(1):41-6.

33. Levine A, Koletzko S, Turner D, Escher JC, Cucchiara S, de Ridder L, Kolho KL, Veres G, Russell RK, Paerregaard A, et al. ESPGHAN revised porto criteria for the diagnosis of inflammatory bowel disease in children and adolescents. J Pediatr Gastroenterol Nutr. 2014;58(6):795-806.

34. Kim HJ, Oh SH, Kim DY, Lee HS, Park SH, Yang SK, Kim KM. Clinical Characteristics and Long-Term Outcomes of Paediatric Crohn's Disease: A Single-Centre Experience. J Crohns Colitis. 2017;11(2):157-64.

35. Hyams JS, Ferry GD, Mandel FS, Gryboski JD, Kibort PM, Kirschner BS, Griffiths AM, Katz AJ, Grand RJ, Boyle JT, et al. Development and validation of a pediatric Crohn's disease activity index. J Pediatr Gastroenterol Nutr. 1991;12(4):439-47.

36. Hyams J, Markowitz J, Otley A, Rosh J, Mack D, Bousvaros A, Kugathasan S, Pfefferkorn M, Tolia V, Evans J, et al. Evaluation of the pediatric crohn disease activity index: a prospective multicenter experience. J Pediatr Gastroenterol Nutr. 2005:41(4):416-21.

37. Kim JH, Yun S, Hwang SS, Shim JO, Chae HW, Lee YJ, Lee JH, Kim SC, Lim D, Yang SW, et al. The 2017 Korean National Growth Charts for children and adolescents: development, improvement, and prospects. Korean J Pediatr. 2018;61(5):135-49.

38. Hyun SE, Lee BC, Suh BK, Chung SC, Ko CW, Kim HS, Lee KH, Yang SW, Shin $\mathrm{CH}$, Hwang JS, et al. Reference values for serum levels of insulin-like growth factor-I and insulin-like growth factor binding protein-3 in Korean children and adolescents. Clin Biochem. 2012;45(1-2):16-21.

39. Greulich WWPS: Radiographic atlas of skeletal development of the hand and wrist. Stanford University Press 1959.

40. Lim JS, Hwang JS, Lee JA, Kim DH, Park KD, Cheon GJ, Shin CH, Yang SW. Bone mineral density according to age, bone age, and pubertal stages in korean children and adolescents. J Clin Densitom. 2010; 13(1):68-76.

41. Kang MJ, Hong HS, Chung SJ, Lee YA, Shin CH, Yang SW. Body composition and bone density reference data for Korean children, adolescents, and young adults according to age and sex: results of the 2009-2010 Korean National Health and Nutrition Examination Survey (KNHANES). J Bone Miner Metab. 2016:34(4):429-39.

42. Fan B, Lu Y, Genant H, Fuerst T, Shepherd J. Does standardized BMD still remove differences between Hologic and GE-Lunar state-of-the-art DXA systems? Osteoporos Int. 2010;21(7):1227-36.

43. Palmert MR, Dunkel L. Clinical practice. Delayed puberty. N Engl J Med. 2012;366(5):443-53.

44. Holick MF, Binkley NC, Bischoff-Ferrari HA, Gordon CM, Hanley DA, Heaney $\mathrm{RP}$, Murad MH, Weaver CM, Endocrine S. Evaluation, treatment, and prevention of vitamin D deficiency: an Endocrine Society clinical practice guideline. J Clin Endocrinol Metab. 2011;96(7):1911-30.

45. Shuhart CR, Yeap SS, Anderson PA, Jankowski LG, Lewiecki EM, Morse LR, Rosen HN, Weber DR, Zemel BS, Shepherd JA: Executive Summary of the 2019 ISCD Position Development Conference on Monitoring Treatment, DXA Cross-calibration and Least Significant Change, Spinal Cord Injury, Periprosthetic and Orthopedic Bone Health, Transgender Medicine, and Pediatrics. J Clin Densitom 2019, 22(4):453-471.

46. D'Mello S, Trauernicht A, Ryan A, Bonkowski E, Willson T, Trapnell BC, Frank SJ, Kugasathan S, Denson LA. Innate dysfunction promotes linear growth failure in pediatric Crohn's disease and growth hormone resistance in murine ileitis. Inflamm Bowel Dis. 2012:18(2):236-45.

47. Sawczenko A, Ballinger AB, Savage MO, Sanderson IR. Clinical features affecting final adult height in patients with pediatric-onset Crohn's disease. Pediatrics. 2006;118(1):124-9. 
48. Heuschkel R, Salvestrini C, Beattie RM, Hildebrand H, Walters T, Griffiths A. Guidelines for the management of growth failure in childhood inflammatory bowel disease. Inflamm Bowel Dis. 2008;14(6):839-49.

49. Spray C, Debelle GD, Murphy MS. Current diagnosis, management and morbidity in paediatric inflammatory bowel disease. Acta Paediatr. 2001; 90(4):400-5.

50. Ballinger A. Fundamental mechanisms of growth failure in inflammatory bowel disease. Hormone Res. 2002;58(Suppl 1):7-10.

51. Wine E, Reif SS, Leshinsky-Silver E, Weiss B, Shaoul RR, Shamir R, Wasserman D, Lerner A, Boaz M, Levine A. Pediatric Crohn's disease and growth retardation: the role of genotype, phenotype, and disease severity. Pediatrics. 2004;114(5):1281-6.

52. Malik S, Ahmed SF, Wilson ML, Shah N, Loganathan S, Naik S, Bourke B, Thomas A, Akobeng AK, Fagbemi A, et al. The effects of anti-TNF-alpha treatment with adalimumab on growth in children with Crohn's disease (CD). J Crohns Colitis. 2012;6(3):337-44.

53. Sawczenko A, Sandhu BK. Presenting features of inflammatory bowel disease in Great Britain and Ireland. Arch Dis Child. 2003;88(11):995-1000.

54. Timmer A, Behrens R, Buderus S, Findeisen A, Hauer A, Keller KM, Kliemann G, Lang T, Lohr W, Rzehak P, et al. Childhood onset inflammatory bowel disease: predictors of delayed diagnosis from the CEDATA Germanlanguage pediatric inflammatory bowel disease registry. J Pediatr. 2011; 158(3):467-73 e462.

55. Gordon CM, Ackerman KE, Berga SL, Kaplan JR, Mastorakos G, Misra M, Murad MH, Santoro NF, Warren MP. Functional Hypothalamic Amenorrhea: An Endocrine Society Clinical Practice Guideline. J Clin Endocrinol Metab. 2017;102(5):1413-39.

56. Alkhouri RH, Hashmi H, Baker RD, Gelfond D, Baker SS. Vitamin and mineral status in patients with inflammatory bowel disease. J Pediatr Gastroenterol Nutr. 2013;56(1):89-92.

57. Sadeghian M, Saneei P, Siassi F, Esmaillzadeh A. Vitamin D status in relation to Crohn's disease: Meta-analysis of observational studies. Nutrition (Burbank Los Angeles County Calif). 2016;32(5):505-14.

58. Munns CF, Shaw N, Kiely M, Specker BL, Thacher TD, Ozono K, Michigami T, Tiosano D, Mughal MZ, Makitie O, et al. Global Consensus Recommendations on Prevention and Management of Nutritional Rickets. J Clin Endocrinol Metab. 2016;101(2):394-415.

59. Lim WC, Hanauer SB, Li YC. Mechanisms of disease: vitamin D and inflammatory bowel disease. Nat Clin Pract Gastroenterol Hepatol. 2005;2(7): 308-15.

60. Cantorna MT. Vitamin D and its role in immunology: multiple sclerosis, and inflammatory bowel disease. Prog Biophys Mol Biol. 2006;92(1):60-4.

61. Fletcher J, Cooper SC, Ghosh S, Hewison M. The Role of Vitamin D in Inflammatory Bowel Disease: Mechanism to Management. Nutrients 2019, 11(5).

62. Abraham BP, Prasad P, Malaty HM. Vitamin D deficiency and corticosteroid use are risk factors for low bone mineral density in inflammatory bowel disease patients. Dig Dis Sci. 2014;59(8):1878-84.

63. Maratova K, Hradsky O, Matyskova J, Copova I, Soucek O, Sumnik Z, Bronsky J. Musculoskeletal system in children and adolescents with inflammatory bowel disease: normal muscle force, decreased trabecular bone mineral density and low prevalence of vertebral fractures. Eur J Pediatr. 2017; 176(10):1355-63.

64. Veerappan SG, O'Morain CA, Daly JS, Ryan BM. Review article: the effects of antitumour necrosis factor-alpha on bone metabolism in inflammatory bowel disease. Aliment Pharmacol Ther. 2011;33(12):1261-72.

65. Kappelman MD, Galanko JA, Porter CQ, Sandler RS. Risk of diagnosed fractures in children with inflammatory bowel diseases. Inflamm Bowel Dis. 2011;17(5):1125-30.

66. Targownik LE, Bernstein CN, Nugent Z, Johansson H, Oden A, McCloskey E, Kanis JA, Leslie WD. Inflammatory bowel disease and the risk of fracture after controlling for FRAX. J Bone Miner Res. 2013;28(5):1007-13.

\section{Publisher's Note}

Springer Nature remains neutral with regard to jurisdictional claims in published maps and institutional affiliations.

Ready to submit your research? Choose BMC and benefit from:

- fast, convenient online submission

- thorough peer review by experienced researchers in your field

- rapid publication on acceptance

- support for research data, including large and complex data types

- gold Open Access which fosters wider collaboration and increased citations

- maximum visibility for your research: over $100 \mathrm{M}$ website views per year

At BMC, research is always in progress.

Learn more biomedcentral.com/submissions 